\title{
OVERCOMING SEED DORMANCY IN Annona macroprophyllata AND Annona purpurea USING PLANT GROWTH REGULATORS ${ }^{1}$
}

\author{
GISELA FERREIRA², IVAN DE-LA-CRUZ-CHACÓN , ALMA ROSA GONZÁLEZ-ESQUINCA ${ }^{4}$
}

RESUMO-Sementes de Annonaceae são conhecidas por possuírem mecanismos de dormência que variam de impermeabilidade de tegumento até à dormência fisiológica. Desta forma, o objetivo deste estudo foi avaliar os efeitos da giberelina $\mathrm{GA}_{3}$ e de $\mathrm{GA}_{4+7}+$ a citocinina benziladenina (GA+BA) na superação da dormência de sementes de Annona macroprophyllata Donn. Sm (papausa) e Annona purpurea Moc. \& Sessé ex Dunal (chincuya). O experimento foi realizado com a aplicação de $\mathrm{GA}_{3}$ e $\mathrm{GA}_{4+7}+\mathrm{BA}$ nas concentrações de 0; $200,400,500,600,800$ e $1.000 \mathrm{mg} \mathrm{L}^{-1}$. O uso dos reguladores resultou na quebra da dormência em ambas as espécies. Contudo, a aplicação da mistura $\mathrm{GA}_{4+7}+\mathrm{BA}$ resultou em maiores incrementos na germinação de A. macroprophyllata do que em A. purpurea. Os tratamentos que promoveram as maiores porcentagens de germinação foram $200 \mathrm{mg} \mathrm{L}^{-1}$ de $\mathrm{GA}_{4+7}+\mathrm{BA}$ para A. macroprophyllata $(77 \%)$ e $200 \mathrm{mg} \mathrm{L}^{-1} \mathrm{de} \mathrm{GA}_{4+7}+$ BA e $500 \mathrm{mg} \mathrm{L}^{-1}$ de $\mathrm{GA}_{3}$ para $A$. purpurea (30\% e $29 \%$, respectivamente). O índice de velocidade, o tempo médio e a frequência de germinação foram diferentes para ambas as espécies e com ambos os reguladores. Conclui-se que, apesar de $\mathrm{GA}_{3}$ e $\mathrm{GA}_{4+7}+\mathrm{BA}$ promoverem a germinação, a mistura $\mathrm{GA}_{4+7}+\mathrm{BA}$ foi mais efetiva que $\mathrm{GA}_{3}$ para quebrar a dormencia de ambas as espécies. Além disso, sementes de A. purpurea apresentam dormência mais difícil de ser superada que A. macroprophyllata.

Termos de indexação: Annonaceae, $\mathrm{GA}_{3}, \mathrm{GA}_{4+7}, \mathrm{~N}$-(fenilmetil)-aminopurina, germinação-Annonaceae, Annona diversifolia.

\section{SUPERAÇÃO DA DORMÊNCIA DE SEMENTES DE Annona macroprophyllata E Annona purpurea COM O USO DE REGULADORES VEGETAIS}

\begin{abstract}
Some Annonaceae seeds are known to exhibit dormancy mechanisms ranging from possible seed coat impermeability to physiological dormancy. Thus, the aim of this study was to evaluate the effects of gibberellin (GA) $\mathrm{GA}_{3}$ and $\mathrm{GA}_{4+7}+$ benzyladenine $\left(\mathrm{GA}_{4+7}+\mathrm{BA}\right)$ application in seeds of Annona macroprophyllata Donn. Sm (papausa) and Annona purpurea Moc. \& Sessé ex Dunal (chincuya). The experiment was performed by the application of $\mathrm{GA}_{3}$ and $\mathrm{GA}_{4+7}+\mathrm{BA}$ on seeds in concentrations of 0 , $200,400,500,600,800$ and $1000 \mathrm{mg} \mathrm{L}^{-1}$. The regulators broke the dormancy of both species. However, application of the $\mathrm{GA}_{4+7}+\mathrm{BA}$ mixture had more significant results, with greater increases in germination in A. macroprophyllata than in A. purpurea. Treatments that promoted the highest germinations were $\mathrm{GA}_{4+7}$ $+\mathrm{BA}$ at a concentration of $200 \mathrm{mg} \mathrm{L}^{-1}$ for A. macroprophyllata (77\%) and $200 \mathrm{mg} \mathrm{L}^{-1} \mathrm{of} \mathrm{GA}_{4+7}+\mathrm{BA}$ and $500 \mathrm{mg} \mathrm{L}^{-1}$ of $\mathrm{GA}_{3}$ for $A$. purpurea (30\% and $29 \%$, respectively). Rate index, mean time and frequency of germination were distinct for both species and both treatments. Although both $\mathrm{GA}_{3}$ and $\mathrm{GA}_{4+7}+\mathrm{BA}$ promote germination, the $\mathrm{GA}_{4+7}+\mathrm{BA}$ mixture was more effective than $\mathrm{GA}_{3}$ to overcoming seed dormancy of both species, $A$. purpurea has a harder dormancy than $A$. macroprophyllata
\end{abstract}

Index terms: Annonaceae, $\mathrm{GA}_{3}, \mathrm{GA}_{4+7}, \mathrm{~N}$-(phenylmethyl)-aminopurine, germination-Annonaceae, Annona diversifolia.

\footnotetext{
${ }^{1}$ (Trabalho 128-15). Recebido em: 11-05-2015. Aceito para publicação em: 01-03-2016. Parte de projeto realizado em pósdoc pelo primeiro autor financiado pela CAPES.

${ }^{2}$ Departamento de Botânica, Instituto de Biociencias de Botucatu, Universidade Estadual Paulista (UNESP), distrito de Rubião Junior, Botucatu, São Paulo, Brasil, caixa postal 510,CEP:18.608-540. E-mail: gisela@ibb.unesp.br

${ }^{3}$ Laboratorio de Fisiología y Química Vegetal. Instituto de Ciencias Biológicas 2 , Universidad de Ciencias y Artes de Chiapas (UNICACH). Libramiento Norte Poniente 1150. Col. Lajas Maciel, C.P. 29039. Tuxtla Gutiérrez, Chiapas, México. E-mail: ivan.cruz@unicach.mx ${ }^{4}$ Laboratorio de Fisiología y Química Vegetal. Instituto de Ciencias Biológicas, Universidad de Ciencias y Artes de Chiapas (UNICACH). Libramiento Norte Poniente 1150. Col. Lajas Maciel, C.P. 29039. Tuxtla Gutiérrez, Chiapas, México.E mail autor corresponding: aesquinca@unicach.mx
} 


\section{INTRODUCTION}

Plant hormones are involved in several plant mechanisms like dormancy and germination. Gibberellins (GA) are diterpenoids biosynthesized from geranyldiphosphate that present antagonistic effect with ABA to release seeds from dormancy. GAs induce the synthesis of hydrolases enzymes like $\alpha$-amylases, proteases and $\beta$-glucanases (NONOGAKY et al., 2010) that act in endosperm weakening, and organ expansion during seed germination (VOEGELE et al., 2011). In addition of ABA and GA, Cytokinis (CK), plant hormones derived from adenine molecules, has been related with important role in seed germination due to antagonizes ABA and promote early seedling growth (GUAN et. al., 2014). Besides CKs are able to regulate different functions related to embryo development by affecting the cellular division, seed germination, hypocotyls and shoot growth (MIRANSARI;SMITH, 2014).

The seeds of several Annonaceae species exhibit some type of dormancy. Annona macroprophyllata Donn. Sm (papausa) and Annona purpurea Moc. \& Sessé ex Dunal (chincuya) are from the low deciduous forest in Southeastern Mexico and Central America and the second species inhabits also in SouthAmerica, are edible species consumed fresh and regionally traded. Both species exhibit dormant seeds, likely reflecting an ecological adaptation given that they are dispersed at the end of the rainy season. For both species, the dormancy period varies between six and eight months (GONZÁLEZ ESQUINCA et al. 2016), (GONZALES-ESQUINCA et al.,2015).

Considering the morphological aspects of seeds of A. macroprophyllata, GonzalezEsquinca et al. (1997) in Ferreira et al. (2014) found that although the embryos are small, there is differentiation in embryonic tissues during dispersion. Furthermore, during the duration of the dormancy of A. macroprophyllata seeds (seven months), there were no anatomical changes. Additionally, GomézCastañeda et al. (2003) report that $A$. purpurea seeds have a dormancy period of more than six months of storage; after this period, only seeds treated with the gibberellin $\mathrm{GA}_{3}$ are able to germinate.

In a study with $A$. cherimola and $A$. diversifolia seeds, Campbell and Popenoe (1968) achieved $80 \%$ germination using 350 to 500 mg.L $\mathrm{L}^{-1}$ of $\mathrm{GA}_{3}$. For atemoya (A.cherimolla $x \mathrm{~A}$. squamosa) cv Gefner, $778 \mathrm{mg} \mathrm{L}^{-1}$ of GA $\mathrm{G}_{3}$ promoted $80 \%$ germination, (OLIVEIRA et al., 2010). Considering the mixture of growth regulators, Da Silva et al. (2007) broke dormancy in A crassiflora
Mart. seeds (43\% germination) using $143 \mathrm{mg} \mathrm{L}^{-1}$ of $\mathrm{GA}_{4+7}$. In Xylopia aromatica seeds, $63 \%$ of seedling emergence was observed using a $\mathrm{GA}_{4+7}+$ cytokinin $\mathrm{N}$-(phenylmethyl)-aminopurine mixture (SOCOLOWSKI et al., 2011) and in atemoya, cv Gefner, 95\% of germination with $329 \mathrm{mg} \mathrm{L}^{-1}$ (BRAGA et al., 2010). Therefore, considering the importance of hormones in overcoming dormancy in seeds and in germinative processes, the aim of this study was to determinate if the dormancy of $A$. macrophyllata and A. purpurea seeds would be able to break with the exogenous application of $\mathrm{GA}_{3}$ and $\mathrm{GA}_{4+7}+$ benzyladenine (BA) mixture and the posmaturation period reduced.

\section{MATERIAL AND METHODS}

\section{Plant data collection}

To perform the experiments, fruits of $A$. macroprophyllata Donn. Smth and A. purpurea Moc \& Sessé ex Dunal were obtained in San Lucas, Chiapas, Mexico. Seeds were manually extracted under running water, immersed in sodium hypochlorite $(3 \%)$ for 5 minutes and washed in distilled water. The seeds were then placed on filter paper for seven days on top of a laboratory bench ( 25 ${ }^{\circ} \mathrm{C}+/-2{ }^{\circ} \mathrm{C}$ ) for surface drying. The initial moisture content of the seeds $(10 \%)$ was determined using the oven-drying method at $105{ }^{\circ} \mathrm{C}$ for $24 \mathrm{~h}$, with four replicates of 25 seeds each (CORSATO et al., 2012). Additionally, seed viability was evaluated using the tetrazolium test with four replicates of 25 seeds each.

Evaluation of the effects of growth regulators on seed dormancy

The experimental design was a completely randomised $2 \times 7$ (regulators $\mathrm{x}$ concentrations) factorial design with 4 replicates of 25 seeds each. The growth regulators were $\mathrm{GA}_{3}$ and $\mathrm{GA}_{4}{ }_{7}+$ $\mathrm{N}$-(phenylmethyl)-aminopurine (benzyladenine) mixture, and the concentrations: 0, 200, 400, 500, 600,800 and $1000 \mathrm{mg} \mathrm{L}^{-1}$.

Seeds were treated by immersion in growth regulators solutions over 96 hours under constant aeration. This period was established considering the water uptake curve previously performed (FERREIRA et al., 2014). After treatments, seeds were placed in a roll of paper moistened with distilled water ( 2.5 times its weight) (CORSATO et al., 2012). Seeds were kept in a germinator at $30^{\circ} \mathrm{C}\left( \pm 2{ }^{\circ} \mathrm{C}\right)$ average temperature at which the seeds are exposed in their habitat with a relative humidity ranging from 50 to $60 \%$ and in the absence of light (GONZALEZ-ESQUINCA et al., 2015)

Observations were made every two days 
from the beginning of the experiment. The number of germinated seeds was also counted during each observation. All seeds with a primary root approximately $2 \mathrm{~mm}$ in length were considered to be germinated.

The following variables were calculated: percentages of germination $(\% \mathrm{G})$, dormant seeds $(\% \mathrm{DS})$ and dead seeds $(\% \mathrm{DS})$; relative frequency (f) according to CORSATO et al. (2012); germination rate index (GRI) according to Maguire (1962); and mean germination time (MGT) according to Edmond and Drapala (1958), cited by Ranal and Santana (2006). The GRI and MGT values were obtained using the following equations:

$$
\mathbf{G R I}=\Sigma \mathbf{G}_{\mathbf{i}} / \mathbf{T}_{\mathbf{i}}
$$

where GRI = daily germination rate index; $\mathrm{G}_{\mathrm{i}}$ $=$ daily percentage of germination; $\mathrm{T}_{\mathrm{i}}=$ time (in days)

$$
\text { MGT }=\Sigma G_{i} * T_{i} / \Sigma G_{i} S
$$

where $\mathrm{MGT}=$ mean time needed to achieve maximum germination; $G_{i}=$ daily percentage of germination; $\mathrm{T}_{\mathrm{i}}=$ time (in days).

The data were subjected to an analysis of variance, and the means were compared using Tukey's test at a 5\% probability between regulators. Finally, a regression was performed to verify data trends in relation to concentrations. All analyses were performed using SAS (SAS Institute, Cary, NC).

\section{RESULTS}

\section{Effects of growth regulators on total germination}

Among the seeds that were soaked in water for $96 \mathrm{~h}$ before germination, those of $A$. macroprophyllata did not germinate. Seeds of $A$. purpurea, in turn, had a 1 to $4 \%$ germination rate (table 1).

Germination occurred when seeds received growth regulators $(p<0.001)$. There was a trend of a greater percentage of germination when regulators were used at lower concentrations. However, when comparing the effects between growth regulators, it was observed that A. macroprophyllata and $A$. purpurea seeds treated with $\mathrm{GA}_{4+7}+\mathrm{BA}$ mixtures usually had higher percentages of germination than seeds that were treated only with $\mathrm{GA}_{3}$ at all concentrations $(p<0.005)$. The only exception was detected in A. purpurea seeds: the percentage of germination with $\mathrm{GA}_{4+7}+$ BA was lower when 500 $\mathrm{mg} \mathrm{L}^{-1}$ was used, and no differences was observed between regulators when $600 \mathrm{mg} \mathrm{L}^{-1}$ and $800 \mathrm{mg}$ $\mathrm{L}^{-1}$ were used.

Considering the specific effects concerning $\mathrm{GA}_{3}$ application, percentages of germination varied between 19 and 51\% for A. macroprophyllata. The greatest effect was observed with the lower concentration $\left(200 \mathrm{mg} \mathrm{L}^{-1}\right)$, whereas the least effect was detected with the application of the highest concentration (1000 $\left.\mathrm{mg} \mathrm{L}^{-1}\right)$. For A. purpurea, germination ranged from 17 to $29 \%$, and the greatest effect was obtained with the median concentration (500 $\mathrm{mg} \mathrm{L}^{-1}$ ). Considering that seeds remained dormant in the absence of $\mathrm{GA}_{3}$, the observed percentages of germination represent changes induced by $\mathrm{GA}_{3}$ on metabolism.

The effect of the $\mathrm{GA}_{4+7}+\mathrm{BA}$ mixture on A. macroprophyllata seeds resulted in 50 to $77 \%$ germination (with 1000 and $200 \mathrm{mg} \mathrm{L}^{-1}$, respectively), whereas in $A$. purpurea seeds, the germination percentages varied between 25 and $30 \%$ (with $1000 \mathrm{mg} \mathrm{L}^{-1}$ and $200 \mathrm{mg} . \mathrm{L}^{-1}$ ). For both species, the greatest percentages were obtained using lower concentrations $(p<0.005)$, as observed in the trend lines of both species (table 1 and figure 1).

After evaluating germination percentage, seeds that did not germinate were evaluated using a viability test (tetrazolium test), enabling the distinction between dead and dormant seeds. Therefore, only the percentage of dead seeds is presented, given that the number of dormant seeds may be calculated by subtracting the germinated and dead seeds from all evaluated seeds (table 2).

The number of dead A. macroprophyllata seeds was equal to the control (3-9\%) when the $\mathrm{GA}_{4+7}+\mathrm{BA}$ mixture was used $(p>0.05)$. Only GA application at high concentrations (600 to $1000 \mathrm{mg}$ $\left.\mathrm{L}^{-1}\right)$ induced $11-15 \%$ of dead seeds. However, for A. purpurea, no differences were observed between dead seeds treated with growth regulators (in any of the concentrations) and the control, suggesting that the mortality percentage reflects characteristics of this species (table 2). Therefore, growth regulator application was not the cause of seed mortality $(p$ $>0.05$ ).

In addition to their action on the germination process (modifying germination percentages), growth regulators also affected the speed at which the process occurred (figure 2), the mean time (table 3 ) and the frequency (figure 3).

Speed of germination of A. macroprophyllata seeds follows a similar trend to germination 
percentage: higher speeds usually occur under lower concentrations of growth regulators. It must be highlighted that $\mathrm{GA}_{4+7}+\mathrm{BA}$, when compared to the use of $\mathrm{GA}_{3}$, promoted the highest speeds at all concentrations. The mean time needed for germination was reduced by the use of lower concentrations of both regulators $(p<0.05)$. However, differences between $\mathrm{GA}_{4+7}+\mathrm{BA}$ and $\mathrm{GA}_{3}$ on the reduction of mean germination time were observed only with concentrations of 200, 400 and $1000 \mathrm{mg} \mathrm{L}^{-1}(p<0.05)$. The speed of germination, in turn, was higher at each of the concentrations of $\mathrm{GA}_{4+7}+\mathrm{BA}$ when compared to $\mathrm{GA}_{3}$ (figure 2).

Analysis of the relative frequency of $A$. macroprophyllata germination (figure 3) also showed that germination was anticipated and more synchronised with the use of $200 \mathrm{mg} \mathrm{L}^{-1}$ to $600 \mathrm{mg}$ $\mathrm{L}^{-1}$ of $\mathrm{GA}_{3}$ when compared to higher concentrations. For $\mathrm{GA}_{4+7}+\mathrm{BA}$ applied in concentrations up to $500 \mathrm{mg} \mathrm{L}^{-1}$, there was a higher concentration of germinated seeds at the beginning of the period in addition to the increase in the germination percentage. Higher concentrations of $\mathrm{GA}_{4+7}+\mathrm{BA}$ reduced germination percentages and induced a more dispersed germination of seeds over time.

Additionally, A. purpurea seeds treated with $\mathrm{GA}_{4+7}+\mathrm{BA}$ germinated faster than seeds treated with $\mathrm{GA}_{3}$. The only exception was the case of seeds treated with concentrations of $500 \mathrm{mg} \mathrm{L}^{-1}$ : there was no significant difference between regulators. Higher speeds were achieved using lower concentrations of $\mathrm{GA}_{4+7}+\mathrm{BA}$ and intermediate concentrations of $\mathrm{GA}_{3}$ (figure 3). While the use of $\mathrm{GA}_{4+7}+\mathrm{BA}$ promoted the highest speeds of germination, the lowest mean times were obtained with the concentrations of 200 , 400, 600 and $1000 \mathrm{mg} . \mathrm{L}^{-1}$ compared to $\mathrm{GA}_{3}$ (Table 4). Therefore, there is no trend between this response and growth regulator concentrations.

$A$. purpurea seeds (figure 3) germinated more slowly and were less synchronised than $A$. macroprophyllata seeds. Additionally, A. purpurea seeds treated with $200 \mathrm{mg} \mathrm{L}^{-1}$ and $400 \mathrm{mg} \mathrm{L}^{-1}$ of $\mathrm{GA}_{4+7}+\mathrm{BA}$ had the highest germination percentages. However, seeds treated with $400 \mathrm{mg} \mathrm{L}^{-1}$ also germinated mainly at the beginning of the period, reducing the mean time of germination.

\section{DISCUSSION}

The analysis of the findings for distinct variables of germination confirmed the dormancy of A. macroprophyllata and A. purpurea seeds. The action of growth regulators in overcoming dormancy was also corroborated like observed in other Annonaceae, atemoya (Annona cherimolla Mill. x A. squamosa L.) (BRAGA et al., 2010; OLIVEIRA et al., 2010), A. crassiflora (DA SILVA et al., 2007) and $X$. aromatica (SOCOLOWSKI et al., 2011).

Overall, the results suggest that in the $A$. macroprophyllata and A. purpurea seeds of the present study, immersion in water was insufficient to activate de novo GA synthesis and to antagonise ABA effects, because in this condition the seeds did not germinate. This insufficiency suggests the establishment of primary dormancy due to ABA accumulation during seed development (NAMBARA et al, 2010). Therefore, exogenous applications of growth regulators $\left(\mathrm{GA}_{3}, \mathrm{GA}_{4+7}+\mathrm{BA}\right)$ changed the hormonal balance and were favourable to overcome dormancy and promote germination of seeds from both species.

In this sense, although in this work the gen expression did not was evaluated, the literature is clear to report that GAs reduce the expression of ABA-responsive genes, and induce the expression of genes encoding enzymes that degrade reserves and release energy to the embryo (e.g., amylases) and that degrade the cell walls of endosperm cells, facilitating radicle protrusion (NONOGAKI et al., 2010).

The observed results of the effect of $\mathrm{GA}_{3}$ application in A. macroprophyllata differ from previous findings. Campbell and Popenoe (1968) suggest that the application of $\mathrm{GA}_{3}$ in concentrations from 350 to $500 \mathrm{mg} \mathrm{L}^{-1}$ would enhance seed germination percentages from 30 to $80 \%$ respectively. However, in the present experiment, the percentages of A. macroprophyllata germination of were $19 \%$ and $51 \%$ with 1000 and $200 \mathrm{mg} \mathrm{L}^{-1}$ of $\mathrm{GA}_{3}$, respectively.

In contrast, González-Esquinca et al. (1997) cited in Ferreira et al. (2014) related that only $42 \%$ of germination was observed after the application of $10^{-3} \mathrm{M}\left(346 \mathrm{mg} \mathrm{L}^{-1}\right)$ of $\mathrm{GA}_{3}$ in seeds stored for 18 days and $64 \%$ with seeds stored for two months without $\mathrm{GA}_{3}$ application. This last value is similar to the highest value observed in this study with the use of $\mathrm{GA}_{3}$ in recently collected seeds (51\%). Later, González-Esquinca et al. (2015) found that even when the embryos were completely developed at the time of dispersion, the A. macroprophyllata seeds needed a rest period of approximately seven months to achieve 61 to $71 \%$ germination. It is important said 
that the seeds of these experiments were obtained from the same region (San Lucas city, Chiapas state, Mexico) and were germinated with the same light and temperature conditions (absence of light and 30 ${ }^{\circ} \mathrm{C}, \pm 2{ }^{\circ} \mathrm{C}$ ) indicating that these results confirm the dormancy and necessity of plant growth regulators or storage to germinate.

As observed in this study, application of $\mathrm{GA}_{4+7}+\mathrm{BA}$ in concentrations from 200 to $400 \mathrm{mg}$ $\mathrm{L}^{-1}$ eliminates the need to wait for the rest period ( 6 to 8 months) to break dormancy. These regulators yielded increases in the entire germination process, from increases in germination percentage and speed to greater synchronicity of germination, favouring plant management in seedling nurseries.

Therefore, under suitable environmental conditions or when receiving stimuli through the application of growth regulators on seeds, embryos continue their development and seeds germinate. This development would not be possible with recently dispersed seeds if embryos were incomplete or undifferentiated.

For A. purpurea, no records were found regarding embryo development stage during seed dispersion. However, previous findings reported the high dormancy of this species, with germination of only $8 \%$ after up to six months of fruit extraction (GÓMEZ-CASTAÑEDA et al., 2003). In the present study, recently extracted seeds had 1 to $4 \%$ germination, and even with growth regulators, the highest percentages of germination were $30 \%$ (with $\mathrm{GA}_{4+7}+\mathrm{BA}$ ) and $29 \%$ (with $\mathrm{GA}_{3}$ ). The increases in germination were 4 to 8 times greater for seeds with treatment than for seeds without treatment. Nevertheless, the germination percentage remains low for this species.

Among the regulators used in this study, the $\mathrm{GA}_{4+7}+\mathrm{BA}$ mixture was more effective at overcoming dormancy of $A$. macroprophyllata and $A$. purpurea than $\mathrm{GA}_{3}$. Using the biostimulant $\left(\mathrm{GA}_{4+7}+\right.$ $\mathrm{BA})$ leads to the synergistic effect of the two GAs and the cytokinin, enabling the use of the mixture at lower concentrations. Therefore, considering how growth regulators act, these results suggest that both $\mathrm{GA}_{4}$ and $\mathrm{GA}_{7}$, which are active, functioned to overcome dormancy, antagonising $\mathrm{ABA}$ and promoting germination (NAMBARA et al., 2010; NONOGAKY et al., 2010). Furthermore, there may have been a combined effect of cytokinin, which also acts as an antagonist to both ABA and cell division, even before radicle protrusion (MIRANSARI; SMITH, 2014; GUAN et al., 2014) and observed by Da Silva et al. (2007) in A. crassiflora seeds, suggesting the occurrence of events other than just cell elongation during protrusion.

Even though it promoted increases in germination, high concentrations of $\mathrm{GA}_{4+7}+\mathrm{BA}$ or $\mathrm{GA}_{3}$ reduced germination percentages, for example, with $1000 \mathrm{mg} \mathrm{L}^{-1}$ was observed the minors germinations to A. macroprophyllata seeds, that reduced from $51 \%$ to $19 \%\left(200 \mathrm{mg} \mathrm{L}^{-1}\right.$ of $\left.\mathrm{GA}_{3}\right)$ and from $77 \%$ to $50 \%\left(200 \mathrm{mg} \mathrm{L}^{-1}\right.$ of $\left.\mathrm{GA}_{4+7}+\mathrm{BA}\right)$. This fact suggests that such a finding may be related to the control of GA biosynthesis (YAMAGUCHI, 2008; NONOGAKI et al., 2010). Therefore, high concentrations of GAs, instead of inhibiting ABA action in dormancy reduction and stimulating the synthesis of hydrolytic enzymes and/or de novo GA synthesis, may have acted by controlling the endogenous concentration, thus reducing their effect. The results highlight the key role of growth regulators in overcoming dormancy in A. macroprophyllata and $A$. purpurea seeds. In this sense, it may be considered that physiological dormancy was overcome for A. macroprophyllata. However, in the case of $A$. purpurea, despite the satisfactory results, more studies regarding embryo development are necessary to determine if the observed dormancy is physiological or morphophysiological. 
TABLE 1- Germination (\%) of Annona macroprophyllata and Annona purpurea seeds subjected to treatments with different concentrations of $\mathrm{GA}_{3}$ e $\mathrm{GA}_{4+7}+\mathrm{BA}$

\begin{tabular}{ccccc}
\hline & \multicolumn{3}{c}{ Germination (\%) } & \multicolumn{2}{c}{ Annona purpurea } \\
$\mathrm{mg} \mathrm{L}^{-1}$ & $\mathrm{GA}_{3}$ & $\mathrm{GA}_{4+7}+\mathrm{BA}$ & $\mathrm{GA}_{3}$ & $\mathrm{GA}_{4+7}+\mathrm{BA}$ \\
\hline 0 & $0 \mathrm{Af}^{* 1}$ & $0 \mathrm{Af}$ & $4 \mathrm{Ac}$ & $1 \mathrm{Ae}$ \\
200 & $51 \mathrm{Ba}$ & $77 \mathrm{Aa}$ & $17 \mathrm{Bb}$ & $30 \mathrm{Aa}$ \\
400 & $37 \mathrm{Bbc}$ & $71 \mathrm{Ab}$ & $19 \mathrm{Bb}$ & $29 \mathrm{Aa}$ \\
500 & $39 \mathrm{Bb}$ & $66 \mathrm{Ac}$ & $29 \mathrm{Aa}$ & $27 \mathrm{Bab}$ \\
600 & $35 \mathrm{Bc}$ & $60 \mathrm{Ad}$ & $21 \mathrm{Ab}$ & $22 \mathrm{Ac}$ \\
800 & $32 \mathrm{Bd}$ & $59 \mathrm{Ad}$ & $20 \mathrm{Ab}$ & $18 \mathrm{Ad}$ \\
1000 & $19 \mathrm{Be}$ & $50 \mathrm{Ae}$ & $20 \mathrm{Bb}$ & $25 \mathrm{Abc}$ \\
\hline
\end{tabular}

*1.The mean values followed by the same lower case letters in the columns and upper case letters in the rows, for each species, do not differ according to Tukey's test at $\mathrm{p}<0.05$

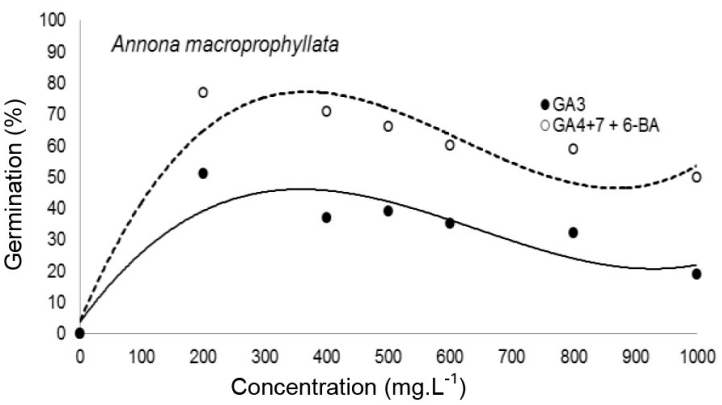

$G_{3}: y=3 E-07 x^{3}-0.0005 x^{2}+0.2719 x+3,7386: R^{2}=0.8068$

$\mathrm{GA}_{4+7}+6-\mathrm{BA}: \mathrm{y}=5 \mathrm{E}-07 \mathrm{x} 3-0.0009 \mathrm{x}^{2}+0,4644 \mathrm{x}+4,098 ; \mathrm{R}^{2}=0.9036$

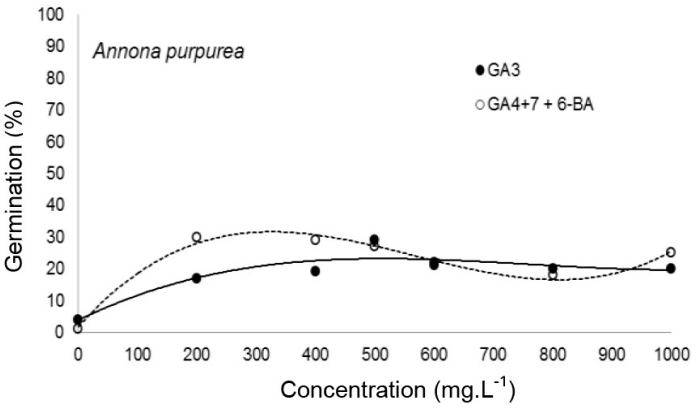

$G_{3}: y=6 E-08 x^{3}-0.0001 x^{2}+0.0911 x+3.785 ; R^{2}=0.8466$ $\mathrm{GA}_{4+7}+$ BAP: $y=3 E-07 x^{3}-0.0005 x^{2}+0.2123 x+1,6396 ; R^{2}=0.9835$

FIGURE 1- Germination (\%) of Annona macroprophyllata and Annona purpurea seeds subjected to treatments with different concentrations of $\mathrm{GA}_{3}$ e $\mathrm{GA}_{4+7}+\mathrm{BA}$

TABLE 2- Dead seeds (\%) of Annona macroprophyllata and Annona purpurea subjected to treatments with different concentrations of $\mathrm{GA}_{3}$ and $\mathrm{GA}_{4+7}+\mathrm{BA}$

\begin{tabular}{ccccc}
\hline & \multicolumn{3}{c}{ Dead Seeds (\%) } & \multicolumn{2}{c}{ Annona purpurea } \\
$\mathrm{mg} \mathrm{L}^{-1}$ & $\mathrm{GA}_{3}$ & $\mathrm{GA}_{4+7}+\mathrm{BA}$ & $\mathrm{GA}_{3}$ & $\mathrm{GA}_{4+7}+\mathrm{BA}$ \\
\hline 0 & $1 \mathrm{Bb}^{* 1}$ & $6 \mathrm{Ab}$ & $4 \mathrm{Aa}$ & $3 \mathrm{Aa}$ \\
200 & $6 \mathrm{Aab}$ & $3 \mathrm{Ab}$ & $4 \mathrm{Aa}$ & $6 \mathrm{Aa}$ \\
400 & $16 \mathrm{Aa}$ & $5 \mathrm{Bb}$ & $6 \mathrm{Aa}$ & $9 \mathrm{Aa}$ \\
500 & $8 \mathrm{Aab}$ & $9 \mathrm{Aab}$ & $6 \mathrm{Aa}$ & $8 \mathrm{Aa}$ \\
600 & $11 \mathrm{Aab}$ & $7 \mathrm{Aa}$ & $7 \mathrm{Aa}$ & $9 \mathrm{Aa}$ \\
800 & $12 \mathrm{Aab}$ & $6 \mathrm{Ab}$ & $2 \mathrm{Aa}$ & $7 \mathrm{Aa}$ \\
1000 & $15 \mathrm{Aa}$ & $3 \mathrm{Bb}$ & $6 \mathrm{Aa}$ & $7 \mathrm{Aa}$ \\
\hline
\end{tabular}

*1. The mean values followed by the same lower case letters in the columns and upper case letters in the rows, for each species, do not differ according to Tukey's test at $\mathrm{p}<0.05$ 


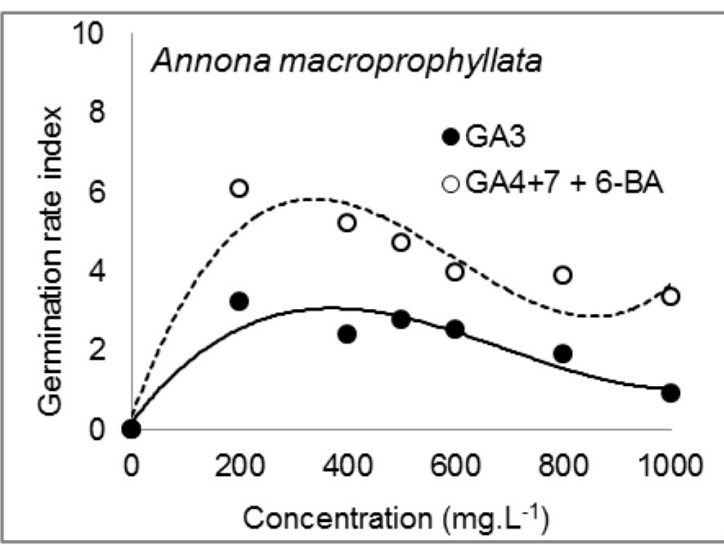

$\mathrm{GA}_{3}: \mathbf{y}=2 \mathrm{E}-08 \mathrm{x}^{3}-3 \mathrm{E}-05 \mathrm{x}^{2}+0,0175 \mathrm{x}+0.2116 ; \mathrm{R}^{2}=0.8585$

$\mathrm{GA}_{4+7}+\mathrm{BAP}: y=4 \mathrm{E}-08 \mathrm{x}^{3}-8 \mathrm{E}-05 \mathrm{x}^{2}+0.0374 \mathrm{x}+0.3416 ; \mathrm{R}^{2}=0.8822$.

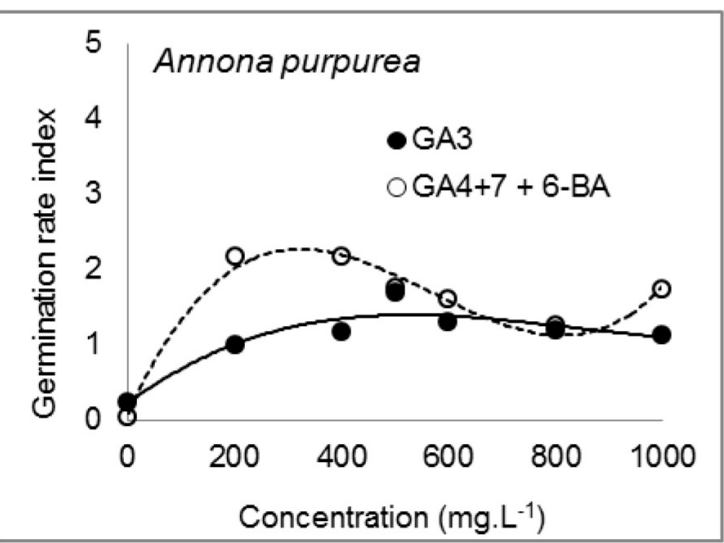

$\mathrm{GA}_{3}: \mathrm{y}=3 \mathrm{E}-09 \mathrm{x}^{3}-7 \mathrm{E}-06 \mathrm{x}^{2}+0.0053 \mathrm{x}+0.2264 ; \mathrm{R}^{2}=0.8881$ $\mathrm{GA}_{4+7}+\mathrm{BAP}: y=2 \mathrm{E}-08 \mathrm{x}^{3}-3 \mathrm{E}-05 \mathrm{x}^{2}+0.0155 \mathrm{x}+0.0975 ; \mathrm{R}^{2}=0.9784$

FIGURE 2- Germination rate index of Annona macroprophyllata and Annona purpurea seeds subjected to treatments with different concentrations of $\mathrm{GA}_{3}$ and $\mathrm{GA}_{4+7}+\mathrm{BA}$

TABLE 3-Mean germination time of Annona macroprophyllata and Annona purpurea seeds subjected to treatments with different concentrations of $\mathrm{GA}_{3}$ and $\mathrm{GA}_{4+7}+\mathrm{BA}$

\begin{tabular}{ccccc}
\hline \multicolumn{3}{c}{ Mean germination time } \\
$\mathrm{mg} \mathrm{L}$ & Annona macroprophyllata & \multicolumn{2}{c}{ Annona purpurea } \\
\hline 0 & $\mathrm{GA}_{3}$ & $\mathrm{GA}_{4+7}+\mathrm{BA}$ & $\mathrm{GA}_{3}$ & $\mathrm{GA}_{4+7}+\mathrm{BA}$ \\
\hline 200 & $0 \mathrm{Ad}^{* 1}$ & $0 \mathrm{Ac}$ & $8.62 \mathrm{Ab}$ & $5.25 \mathrm{Ab}$ \\
400 & $17.99 \mathrm{Abc}$ & $13.16 \mathrm{Bc}$ & $18.72 \mathrm{Aa}$ & $14.54 \mathrm{Bab}$ \\
500 & $16.29 \mathrm{Abc}$ & $14.55 \mathrm{Bab}$ & $16.56 \mathrm{Aab}$ & $13.61 \mathrm{Bab}$ \\
600 & $14.85 \mathrm{Ac}$ & $14.72 \mathrm{Aa}$ & $18.26 \mathrm{Aab}$ & $15.76 \mathrm{Aa}$ \\
800 & $14.42 \mathrm{Ac}$ & $16.42 \mathrm{Aa}$ & $17.51 \mathrm{Aa}$ & $13.74 \mathrm{Bab}$ \\
1000 & $18.13 \mathrm{Ab}$ & $15.99 \mathrm{Aa}$ & $18.44 \mathrm{Aa}$ & $15.51 \mathrm{Aa}$ \\
& $22.45 \mathrm{Aa}$ & $15.94 \mathrm{Ba}$ & $18.94 \mathrm{Aa}$ & $14.82 \mathrm{Bab}$ \\
\hline
\end{tabular}

*1. The mean values followed by the same lower case letters in the columns and upper case letters in the rows, for each species, do not differ according to Tukey's test at $\mathrm{p}<0.05$ 

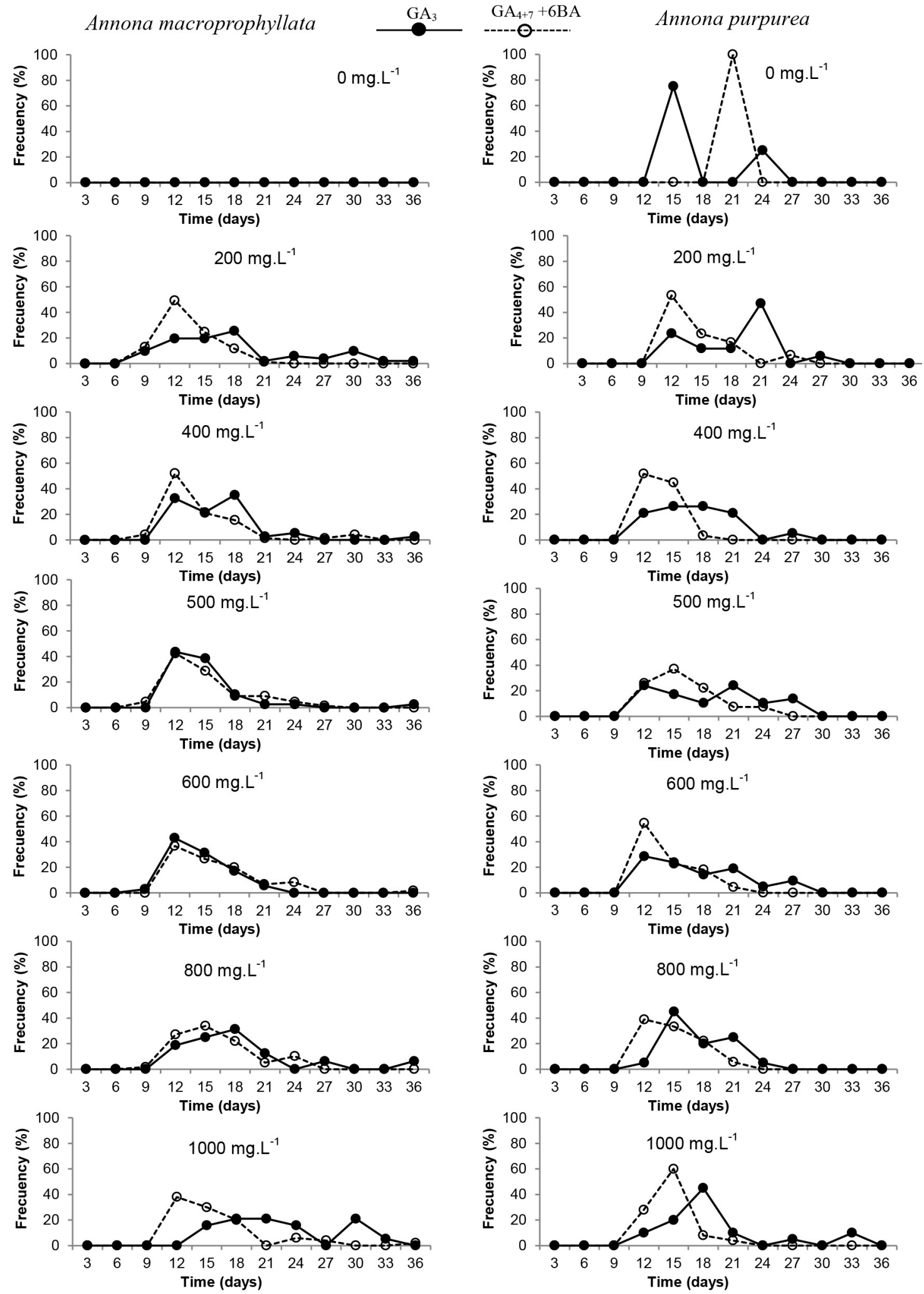

FIGURE 3- Relative germination frequency (\%) of Annona macroprophyllata and Annona purpurea seeds subjected to treatments with different concentrations of $\mathrm{GA}_{3}$ and $\mathrm{GA}_{4+7}+\mathrm{BA}$ 


\section{CONCLUSION}

Therefore the $\mathrm{GA}_{4+7}+\mathrm{BA}$ mixture was more effective than $\mathrm{GA}_{3}$ to overcoming seed dormancy of both species. Besides, A. purpurea has a harder dormancy than A. macroprophyllata.

\section{ACKNOWLEDGEMENTS}

The first author thanks to the Coordenação de Aperfeiçoamento de Pessoal de Nivel Superior (CAPES) for providing schoolarship posdoctorate and also thanks to the Universidad de Ciencias $y$ Artes de Chiapas (UNICACH) for the opportunity to make the postdoc.

\section{REFERENCES}

BRAGA, J.F.; FERREIRA, G.; PINHO, S.Z.; BRAGA, L.F.; SOUSA, M.P. Germination of atemoya (Annona cherimola Mill. x A. squamosa L.) $\mathrm{CV}$. Gefner seeds subjected to treatments with plant growth regulators. International Journal of Science and Nature, Daca, v.1, n. 2, p. 120-126, 2010.

CAMPBELl, C.W.; POPENOE, J. Effect of gibberellic acid on seed dormancy of Annona diversifolia Saff. Tropical Region American Society for Horticultural Service, Mount Vermon, v. 11, p. 31-36, 1968.

CORSATO, J. M.; FERREIRA, G.; BARBEDO, C. J. Desiccation tolerance in seeds of Annona emarginata (Schldtl.) H. Rainer and action of plant growth regulators on germination. Brazilian Journal of Plant Physiology, Campos dos Goytacazes, v.24, n.4, p.253-260, 2012.

DA SILVA, E. A.; DE MELO, D. L.; DAVIDE, A. C.; DE BODE, N.; ABREU, G. B.; FARIA, J. M.; HILHORST, H. W. Germination ecophysiology of Annona crassiflora seeds. Annals of Botany, London, v. 99, n.5, p. 823-830, 2007.

FERREIRA, G.; GONZÁLEZ-ESQUINCA, A.R.; DE-LA-CRUZ-CHACON, I. Water uptake by Annona diversifolia Saff. and A. purpurea Moc. \& Sessé ex Dunal seeds (Annonaceae). Revista Brasileira de Fruticultura, Jaboticabal, v. 36, p. 288-295, 2014. Número Especial
GOMEZ-CASTAÑEDA，J.A.; RAMÍREZ, H.; BENAVIDES-MENDOZA, A.; ENCINARODRIGUEZ, I. Germination and seedling development of soncoya (Annona purpurea Moc y Sessé) in relation to gibberelins and abscisic levels. Revista Chapingo Serie Horticultura, Texcoco, v. 9, n.2, p.243-253, 2003.

GONZÁLEZ-ESQUINCA, A.R.; DE-LACRUZ-CHACÓN, I.; DOMÍNGUEZ-GUTU, L.M.. Dormancy and germination of Annona macroprophyllata Donn. Sm (Annonaceae): the importance of micropylar plug and seed position. Botanical Sciences, Ciudad de México, v.93, n.3, p.1-7, 2015.

GONZÁLEZ-ESQUINCA, A.R.; DE-LA-CRUZCHACÓN I.; CASTRO-MORENO, M.; RILEYSALDAÑA C.A. Phenological strategies of Annona from deciduous forest of Chiapas, Mexico. Botanical Sciences. Ciudad de México, v. 94, n. 3, p. 531-541. 2016.

GUAN, C., WANG, X., FENG, J., HONG, S., LIANG, Y., REN, B., ZUO, J.Cytokinin antagonizes abscisic acid-mediated inhibition of cotyledon greening by promotingthe degradation of ABSCISIC ACID INSENSITIVES protein Arabidopsis. Plant Physiology, Rockville, v. 164, p.1515-1526, 2014.

MIRANSARI, M.; SMITH, D.L. Plant hormones and seed germination. Environmental and Experimental Botany, Oxford, v.99, p.110-121, 2014.

NAMBARA, E.; OKAMOTO, M.; TATEMATSU, K.; YANO, R.; SEO, M.. Abscisic acid and the control of seed dormancy and germination. Seed Science Research, Cambridge, v. 20, p.55-67, 2010.

NONOGAKI, H.; BASSEL,G.W.; BEWLEY, J.D. Germination - still a mystery. Plant Science, Limerick, v. 179, p.574-581, 2010.

OLIVEIRA，M. C. D.; FERREIRA，G.; GUIMARÃEs, V. F.; DIAS, G. B. Germination of atemoya seeds (Annona cherimola Mill. x $A$. squamosa L.) cv 'Gefner' subjected to treatments with Gibberellic acid (GA3) and ethephon. Revista Brasileira de Fruticultura, Jaboticabal, v. 32, n.2, p. 544-554, 2010. 
SOKOLOWSKI, F.; CICERO, S.M. Use of growth regulators to overcome seed dormancy in Xylopia aromatica (Annonaceae). Seed Science and Technology, Zürich, v.39, n.1, p.21-28, 2011.

VOEGELE, A., LINKIES, A., MULlER, K., LEUBNER-METZGER, G. Members of the gibberellin receptor gene family GID1 (Gibberellin Insensitive Dwarf1) playdistinct roles during Lepidium sativum and Arabidopsis thaliana seed germina-tion. Journal of Experimental Botany, Oxford, 155, 1851-1870, 2011.
YAMAGUCHI, S. Gibberellin metabolism and its regulation. Annual Review of Plant Biology, Palo Alto, v. 59, p. 225-251, 2008. 